\title{
Associations between hepatic metabolism of propionate and palmitate in liver slices from transition dairy cows
}

\author{
M. M. McCarthy, M. S. Piepenbrink, and T. R. Overton \\ Department of Animal Science, Cornell University, Ithaca, NY 14853
}

\begin{abstract}
Multiparous Holstein cows $(\mathrm{n}=95)$ were used to evaluate changes in hepatic propionate and palmitate metabolism and liver composition over time during the transition period, along with the relationships of these variables with cumulative increases in nonesterified fatty acids and $\beta$-hydroxybutyrate during the periparturient period. Data from 3 previous experiments were used to address the study objectives, accounting for a total of 95 multiparous Holstein cows. Liver slices from biopsies on $\mathrm{d}-21,1$, and 21 relative to parturition were used to determine conversion of $\left[1-{ }^{14} \mathrm{C}\right]$ palmitate to $\mathrm{CO}_{2}$ and esterified products (EP) and the conversion of $\left[1-{ }^{14} \mathrm{C}\right]$ propionate to $\mathrm{CO}_{2}$ and glucose. Hepatic glycogen content was highest on $\mathrm{d}-21$ and was 26.9 and $36.5 \%$ of prepartum values on $\mathrm{d} 1$ and 21 , respectively. Liver triglyceride content was lowest at $\mathrm{d}-21$ and was 271 and $446 \%$ of prepartum values on d 1 and 21, respectively. We detected no difference in the capacity for the liver to oxidize $\left[1-{ }^{14} \mathrm{C}\right]$ palmitate to $\mathrm{CO}_{2}$ between $\mathrm{d}$ -21 and $\mathrm{d} 1$; however, on d 21, oxidation was $84 \%$ of prepartum values. The capacity of the liver to convert $\left[1-{ }^{14} \mathrm{C}\right]$ palmitate to EP was 148 and $139 \%$ of prepartum values on $\mathrm{d} 1$ and 21 , respectively. The capacity of liver to convert $\left[1-{ }^{14} \mathrm{C}\right]$ propionate to $\mathrm{CO}_{2}$ was 127 and $83 \%$ of prepartum values on $\mathrm{d} 1$ and 21, and the capacity of liver to convert $\left[1-{ }^{14} \mathrm{C}\right]$ propionate to glucose was 126 and $85 \%$ of prepartum values on $\mathrm{d} 1$ and 21 , respectively. Correlation relationships suggest that overall, cows with elevated prepartum liver triglyceride content had elevated triglycerides throughout the transition period along with increased $\left[1-{ }^{14} \mathrm{C}\right]$ palmitate oxidation and conversion to EP and a decreased propensity to convert $\left[1-{ }^{14} \mathrm{C}\right]$ propionate to glucose. Cows with increased [1$\left.{ }^{14} \mathrm{C}\right]$ propionate oxidation had increased conversion of $\left[1-{ }^{14} \mathrm{C}\right]$ propionate to glucose throughout the transition period. Overall, conditions that lead to impairments
\end{abstract}

Received April 9, 2015.

Accepted June 14, 2015.

${ }^{1}$ Corresponding author: tro2@cornell.edu in fatty acid metabolism during the transition period appear to be associated with impaired postpartum hepatic propionate metabolism.

Key words: early lactation, hepatic metabolism, propionate, palmitate

\section{INTRODUCTION}

The metabolic demand of lactation during the immediate postpartum period nearly doubles energy requirements compared with prepartum requirements and results in a state of negative energy balance (Drackley et al., 2001). One of the increases in this metabolic demand of lactation is the need to support milk lactose synthesis in the mammary gland (Bell and Bauman, 1997). At 4 d postpartum, glucose utilization by the mammary gland is estimated to be 2 times greater than that of the gravid uterus during late gestation (Bell, 1995). This rapid increase in glucose demand requires careful orchestration of the metabolic utilization of nutrients for other tissues (Bauman and Currie, 1980).

To accommodate this increase in glucose demand, the liver increases its metabolic activity (Reynolds et al., 2003, 2004). Propionate that is produced from ruminal fermentation is quantitatively the greatest contributor to gluconeogenesis during the periparturient period (Reynolds et al., 2003). However, during the postpartum period, there is a large increase in hepatic utilization of other gluconeogenic precursors (amino acids, lactate, and glycerol) to help meet glucose needs during early lactation (Reynolds et al., 2003). Postpartum endocrine changes and alterations in responses of insulin-dependent tissues to insulin stimulation lead to the sparing of glucose for mammary gland lactose synthesis (Bell, 1995). Because of these glucose-sparing mechanisms, there is decreased lipogenesis and increased lipolysis in adipose tissue (Bell and Bauman, 1997). During the periparturient period, this increase in net lipid mobilization increases the circulating pool of NEFA in the blood stream that can be incorporated into milk fat by the mammary gland, and the proportional uptake of NEFA by the liver also increases (Reynolds et al., 2003). In the liver, these NEFA can 
be oxidized completely to $\mathrm{CO}_{2}$ or partially oxidized to ketone bodies, including BHBA, that can be exported into the circulation for further de novo fatty acid synthesis in the mammary gland and to help meet the energetic needs of peripheral tissues, thereby sparing glucose for mammary lactose synthesis. Hepatic ketone synthesis depends on energy balance and availability of intermediates in the Krebs cycle, and may also be related to individual differences in hepatic gluconeogenic capacity. When there is a large supply of propionate, hepatic ketone body synthesis is reduced (Zammit, 1990; Drackley et al., 2001). When rates of lipid mobilization are high, uptake of NEFA by the liver can exceed the rate of oxidation and also the ability of the liver to export reesterified triglycerides in the form of very low density lipoproteins (VLDL), leading to liver triglyceride accumulation (Drackley, 1999). Excess liver triglyceride accumulation has been associated with a decreased ability for the hepatocyte to synthesize urea (Strang et al., 1998). The consequent increase in liver ammonia may decrease glucose synthesis from propionate (Overton and Drackley, 1999). As such, there are many potential relationships between hepatic gluconeogenesis and FA metabolism. The objective of this study was to further elucidate how these relationships of energy metabolism change during the transition to lactation. We were interested in evaluating changes in hepatic propionate and palmitate metabolism and liver composition over time during the transition period and the relationships between these variables, along with their relationships with the cumulative increases in circulating NEFA and BHBA concentrations during the periparturient period.

\section{MATERIALS AND METHODS}

\section{Experimental Animals and Procedures}

All procedures involving animals were approved by the Cornell University Institutional Animal Care and Use Committee (Ithaca, NY) before the onset of the experiments. Data from 95 Holstein cows entering second lactation or greater from the Cornell University Teaching and Research Center Dairy were used for this data set from 3 separate experiments (Piepenbrink, 2003; Piepenbrink and Overton, 2003; Piepenbrink et al., 2004). Briefly, cows were housed in individual tiestalls and fed the same prepartum and postpartum basal rations within each experiment. Cows received either no dietary treatment (Piepenbrink, 2003), varying amounts of rumen-protected choline (Piepenbrink and Overton, 2003), or varying amounts of 2-hydroxy4-(methylthio)-butanoic acid (Piepenbrink et al., 2004) beginning at $21 \mathrm{~d}$ before expected calving and continu- ing through either d 63 (Piepenbrink, 2003; Piepenbrink and Overton, 2003) or d 84 (Piepenbrink et al., 2004) postpartum.

Plasma samples were obtained 3 times per week via venipuncture of the coccygeal vessels from $d-21$ through d 21 relative to parturition and analyzed for NEFA and BHBA. Plasma concentrations of NEFA and BHBA were analyzed by enzymatic analyses (NEFA-C; Wako Pure Chemical Industries, Osaka, Japan; and BHBA dehydrogenase; kit no. 310, Sigma Chemical, St. Louis, MO).

Liver tissue was sampled via percutaneous trocar biopsy (Veenhuizen et al., 1991) from cows under local anesthesia on $\mathrm{d}-21,1$, and 21 relative to parturition. After blotting the liver sample to remove excess blood and connective tissue, a portion of the sample was immersed in ice-cold PBS $(0.015 \mathrm{M} ; 0.9 \% \mathrm{NaCl}$, $\mathrm{pH}$ 7.4) and transported to the laboratory within 45 min of tissue collection for measurement of in vitro metabolism of $\left[1-{ }^{14} \mathrm{C}\right]$ propionate and $\left[1-{ }^{14} \mathrm{C}\right]$ palmitate as previously described (Piepenbrink, 2003; Piepenbrink and Overton, 2003; Piepenbrink et al., 2004). The remaining portion of liver tissue that was collected was snap-frozen in liquid nitrogen and stored at $-80^{\circ} \mathrm{C}$ until analysis for triglyceride and glycogen content as previously described (Piepenbrink, 2003; Piepenbrink and Overton, 2003; Piepenbrink et al., 2004).

\section{Statistical Analysis}

All statistical computations were performed using SAS software (version 9.3; SAS Institute Inc., Cary, $\mathrm{NC}$ ). Data for hepatic glycogen and triglyceride content, in vitro conversion of $\left[1-{ }^{14} \mathrm{C}\right]$ palmitate to $\mathrm{CO}_{2}$ and esterified products $(\mathbf{E P})$, and conversion of $\left[1-{ }^{14} \mathrm{C}\right]$ propionate to $\mathrm{CO}_{2}$ and glucose and the ratio of glucose to $\mathrm{CO}_{2}$ were subjected to repeated-measures ANOVA using PROC MIXED of SAS and the REPEATED statement. The fixed effect was time and the random effect was cow, and the PDIFF option was used to identify differences within time. Four covariance structures were tested: compound symmetry, heterogeneous compound symmetry, first-order autoregressive, and heterogeneous first-order autoregressive, and the covariance structure that resulted in the smallest Akaike information criterion was used. The degrees of freedom for PROC MIXED were estimated using the KenwardRoger option in the model statement. Least squares means and standard errors of the mean were reported. Statistical significance was declared at $P \leq 0.05$ and trends were discussed at $0.05<P \leq 0.10$.

Thirteen variables (Table 1 ) were chosen to test in Pearson correlation by SAS (2000; SAS Institute Inc., Cary, NC). The area under the curve (AUC) was 
Table 1. Variables used in Pearson correlation analysis

Variable

Hepatic glycogen content on $\mathrm{d}-21$ and $\mathrm{d} 1$ and 21 relative to parturition

Hepatic triglyceride content on $\mathrm{d}-21$ and $\mathrm{d} 1$ and 21 relative to parturition

Capacity of liver to convert $\left[1-{ }^{14} \mathrm{C}\right]$ palmitate to $\mathrm{CO}_{2}$ on $\mathrm{d}-21$ and $\mathrm{d} 1$ and 21 relative to parturition

Capacity of liver to convert $\left[1-{ }^{14} \mathrm{C}\right]$ palmitate to $\mathrm{EP}$ on $\mathrm{d}-21$ and $\mathrm{d} 1$ and 21 relative to parturition

Capacity of liver to convert $\left[1-{ }^{14} \mathrm{C}\right]$ propionate to $\mathrm{CO}_{2}$ on $\mathrm{d}-21$ and $\mathrm{d} 1$ and 21 relative to parturition

Capacity of liver to convert $\left[1-{ }^{14} \mathrm{C}\right]$ propionate to glucose on $\mathrm{d}-21$ and $\mathrm{d} 1$ and 21 relative to parturition

Ratio of converted $\left[1-{ }^{14} \mathrm{C}\right]$ propionate to glucose to $\mathrm{CO}_{2}$ on $\mathrm{d}-21$ and $\mathrm{d} 1$ and 21 relative to parturition

Calculated area under the curve (AUC) for concentrations of NEFA in plasma from d -21 to -1 relative to parturition

Calculated AUC for concentrations of NEFA in plasma from d 1 to 21 relative to parturition

Calculated AUC for concentrations of BHBA in plasma from $\mathrm{d}-21$ to -1 relative to parturition

Calculated AUC for concentrations of BHBA in plasma from d 1 to 21 relative to parturition

Cumulative milk yield during the first $21 \mathrm{~d}$ of lactation

Cumulative DMI from d -7 through d 21 relative to parturition

calculated for both NEFA and BHBA concentrations using the trapezoidal rule as described by Cardoso et al. (2011). If an individual cow was missing more than one-third of the variables, data for that cow were eliminated from the data set before analysis. This resulted in the use of 95 cows; however, some variables only included 80 observations due to missing values.

\section{RESULTS AND DISCUSSION}

\section{Hepatic Glycogen and Triglyceride Content}

Hepatic glycogen content was highest at $\mathrm{d}-21$ and was 26.9 and $36.5 \%$ of prepartum values on $\mathrm{d} 1$ and 21 relative to parturition, respectively (Figure 1). After parturition, hepatic glycogen stores are released into the circulation as another source of glucose during the immediate postpartum period. By d 21 postpartum, hepatic gluconeogenesis has been sufficiently upregulated (Greenfield et al., 2000) such that hepatic glycogen stores begin to be replenished. Interestingly, prepartum concentrations of liver glycogen were not well correlated with glycogen concentrations at d 1 or 21 (Table 2), suggesting that prepartum glycogen stores are not predictive of their postpartum utilization, likely because, to a large extent, all cows mobilize glycogen during the immediate postpartum period (Hammon et al., 2009; Weber et al., 2013b).

Liver triglyceride content was lowest at $\mathrm{d}-21$ and was 271 and $446 \%$ of prepartum values by $\mathrm{d} 1$ and 21, respectively (Figure 1). Liver triglyceride content at $\mathrm{d}-21$ was correlated positively with concentrations of triglyceride in the liver on both d 1 and 21 (Table 2 ), suggesting that cows with higher prepartum liver triglyceride content also had greater accumulation of triglyceride postpartum. Some lipid accumulation in the liver during the periparturient period seems to be a normal adaptation to lactation (Grum et al., 1996); however, excess liver triglyceride accumulation has been shown to impair hepatic metabolism (Strang et al., 1998).

Concentrations of liver glycogen and triglyceride were correlated positively at $\mathrm{d}-21$ (Table 2 ), and cows with higher prepartum glycogen content also had higher triglyceride content prepartum. However, liver sampled on $\mathrm{d} 1$ and 21 relative to parturition had weak negative correlations for concentrations of glycogen and triglyceride, again suggesting that all cows mobilize glycogen postpartum regardless of liver triglyceride content, although cows with lower postpartum glycogen content may have greater depletion of glucose stores (Weber et al., 2013b). Glycogen on d 1 and 21 was correlated negatively with the capacity of liver to convert $\left[1-{ }^{14} \mathrm{C}\right]$ palmitate to EP prepartum and on $\mathrm{d} 1$ and 21, re-

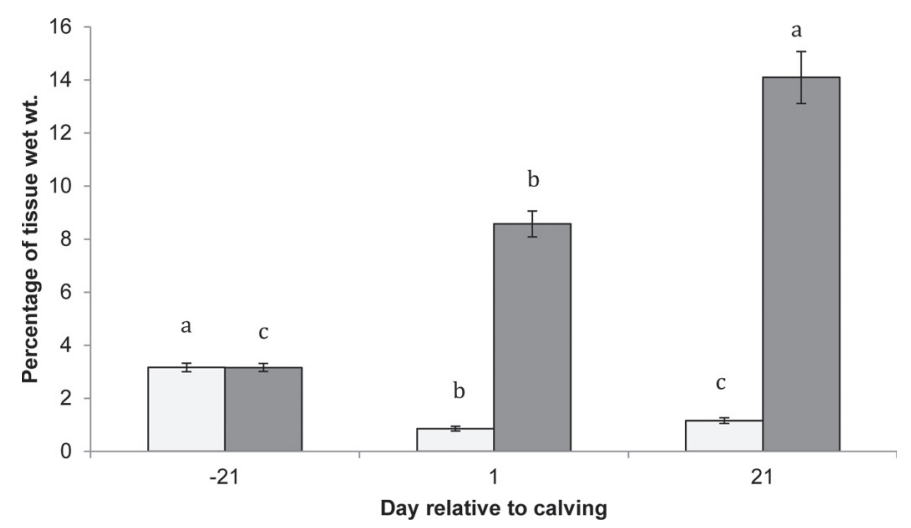

Figure 1. Hepatic glycogen (white bars) and triglyceride (gray bars) contents as a percentage of tissue wet weight in transition dairy cows on $\mathrm{d}-21,1$, and 21 relative to calving. Glycogen content was $3.17,0.85$, and $1.15 \%$ of tissue wet weight relative to calving and triglyceride content was $3.16,8.57$, and $14.09 \%$ of tissue wet weight relative to calving. The effect of day relative to calving was significant for both glycogen $(P<0.0001)$ and triglyceride $(P<0.0001)$. Means with different letters are significantly different $(P=0.05)$; error bars represent $\mathrm{SE}$. 
Table 2. Pearson correlation ${ }^{1}$ among hepatic glycogen and triglyceride content across all other measured variables

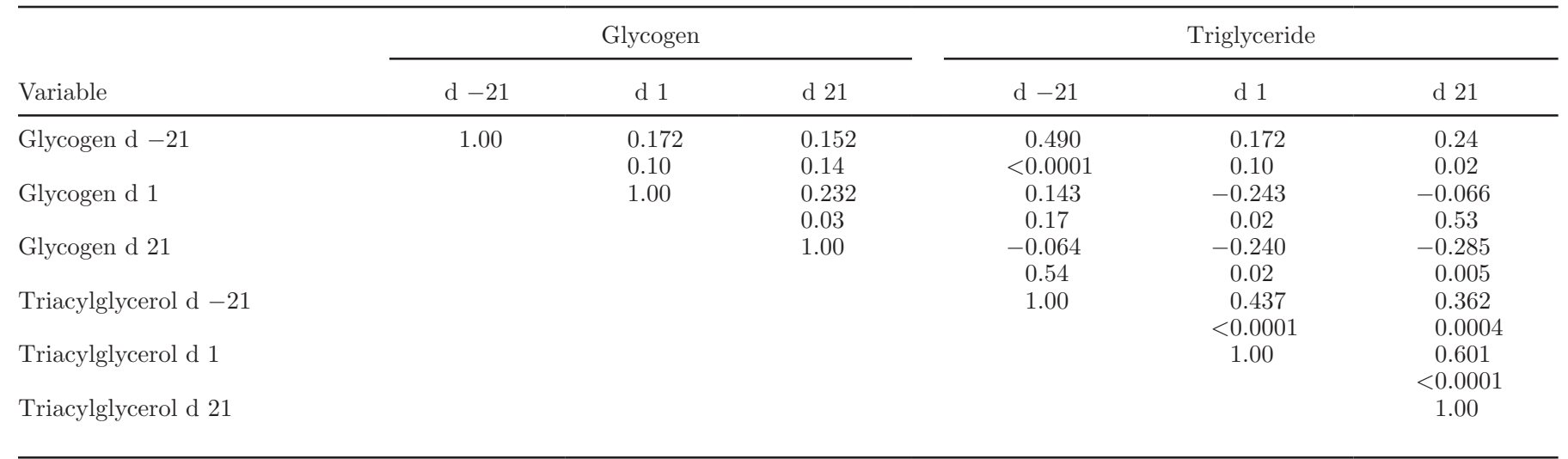

${ }^{1}$ Correlation coefficient (r) is the top number, with corresponding $P$-value beneath.

spectively (Table 3 ), suggesting that cows with greater postpartum glycogen content may have decreased hepatic conversion of palmitate to triglycerides. Weber et al. (2013b) observed that cows classified with low postpartum triglyceride content had greater postpartum glycogen content, higher postpartum DMI, and improved energy balance, although no differences in milk yield were observed. Similarly in the current study, we observed a negative relationship between cumulative periparturient DMI and liver triglyceride content on $\mathrm{d}$ 1 and 21 relative to parturition, although there was no relationship between postpartum liver triglyceride and cumulative milk yield during the first 21 DIM.

Prepartum concentrations of liver triglycerides were positively correlated with liver capacity to convert [1${ }^{14} \mathrm{C}$ ]palmitate to $\mathrm{CO}_{2}$ prepartum (Table 3). Concentrations of liver triglycerides on $\mathrm{d} 1$ relative to parturition were also correlated positively with the capacity of liver to convert $\left[1-{ }^{14} \mathrm{C}\right]$ palmitate to $\mathrm{CO}_{2}$ on $\mathrm{d} 1$; however, relationships were less strong. There was a positive relationship between liver triglyceride content and the capacity of liver to convert $\left[1-{ }^{14} \mathrm{C}\right]$ palmitate to $\mathrm{EP}$ on both d 1 and 21. Litherland et al. (2011) observed that liver slices from overfed dry cows had decreased in vitro capacity to oxidize $\left[1-{ }^{14} \mathrm{C}\right]$ palmitate and increased capacity for esterification on d 1 compared with energyrestricted cows, leading to a greater likelihood for postpartum fatty liver accumulation.

Because of the differences in metabolic demand for high-producing and low-producing cows in early lactation, we stratified our data into cows that were either high producing $(\geq 36 \mathrm{~kg} / \mathrm{d}$ average during the first 21 DIM) or low producing $(<36 \mathrm{~kg} / \mathrm{d}$ average during the first 21 DIM) and performed Pearson correlations. Surprisingly, these relationships had similar directionality and magnitude (data not shown) with the exception of relationships between triglyceride content and in vitro palmitate metabolism. Low-producing cows had a strong relationship between the conversion of $\left[1-{ }^{14} \mathrm{C}\right]$ palmitate to EP and liver triglyceride content on $\mathrm{d}$ 1 postpartum ( $\mathrm{r}=0.69 ; P<0.001$ ), whereas highproducing cows had a poor relationship on $\mathrm{d} 1(\mathrm{r}=$ $0.16 ; P=0.21)$, suggesting that high-producing cows have an increased ability to export triglycerides from the liver compared with low-producing cows during the early postpartum period.

Although we found no relationships between postpartum liver glycogen content and $\left[1-{ }^{14} \mathrm{C}\right]$ propionate conversion to $\mathrm{CO}_{2}$, liver triglyceride content on $\mathrm{d}-21,1$, and 21 relative to parturition was negatively correlated with the capacity of liver to convert $\left[1-{ }^{14} \mathrm{C}\right]$ propionate to $\mathrm{CO}_{2}$ and glucose on $\mathrm{d}-21,1$, and 21 relative to parturition. Transition period liver triglyceride content was also negatively correlated with the ratio of glucose to $\mathrm{CO}_{2}$ at all time points, suggesting that cows with increased liver triglycerides had a reduced propensity to convert propionate to glucose. This may point to a basic negative association between these, although Weber et al. (2013a) observed that cows classified with greater postpartum triglyceride content had impaired mRNA expression of gluconeogenic enzymes.

Interestingly, there was a strong negative correlation between prepartum triglyceride content and prepartum NEFA AUC, such that cows with elevated prepartum liver triglycerides had a lower prepartum NEFA AUC. However, there was a positive relationship between liver triglyceride content at $\mathrm{d} 1$ and 21 and NEFA AUC postpartum, indicating that as more NEFA are released into circulation postpartum, more triglycerides accumulate in the liver. Vazquez-Añon et al. (1994) similarly observed that elevated NEFA on d 1 was strongly related to hepatic triglyceride accumulation, and Strang et al. 
Table 3. Pearson correlation ${ }^{1}$ among hepatic glycogen and triglyceride content across all other measured variables

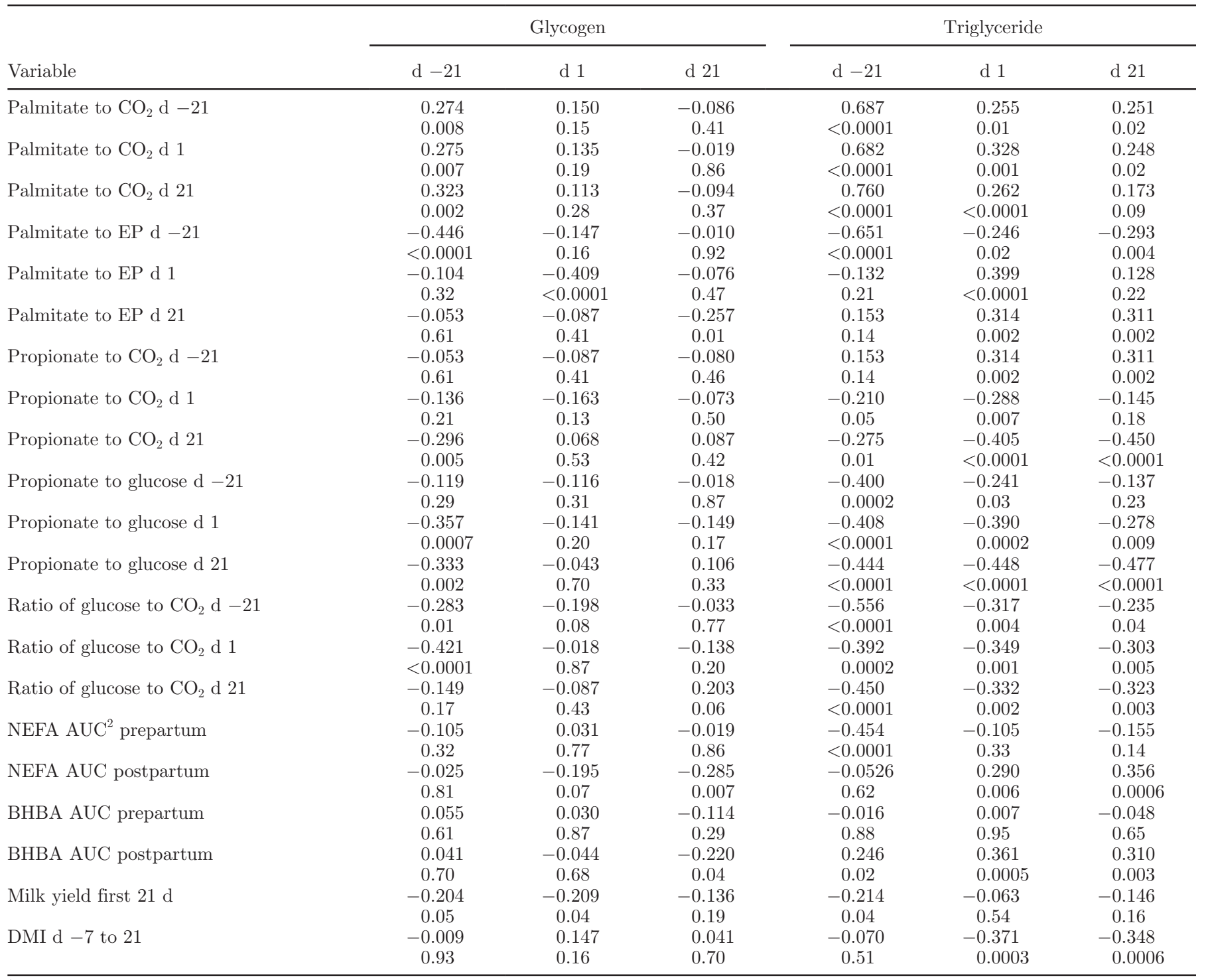

${ }^{1}$ Correlation coefficient (r) is the top number, with corresponding $P$-value beneath.

${ }^{2}$ Area under the curve.

(1998) observed a linear increase in triglyceride content in hepatocytes incubated in vitro with increasing levels of NEFA. This would lead to increased hepatic fatty acid metabolism and greater stored triglyceride in the liver, as Liu et al. (2014) observed decreased gene expression of key enzymes involved in VLDL export for hepatocytes that were incubated in vitro with increasing concentrations of NEFA. Postpartum liver triglyceride content on both $\mathrm{d} 1$ and 21 were also positively correlated with postpartum BHBA AUC, indicating that perhaps as VLDL export is overwhelmed and stored triglycerides accumulate in the liver, there is an increase in the partial oxidation of fatty acids to ketone bodies.

\section{Capacity of Liver to Metabolize Palmitate}

There was no difference in the capacity for the liver to oxidize $\left[1-{ }^{14} \mathrm{C}\right]$ palmitate to $\mathrm{CO}_{2}$ between $\mathrm{d}-21$ and d 1 relative to parturition; however, on d 21, oxidation was $84 \%$ of prepartum values (Figure 2). The capacity of the liver to convert $\left[1-{ }^{14} \mathrm{C}\right]$ palmitate to $\mathrm{EP}$ was 148 and $139 \%$ of prepartum values on $\mathrm{d} 1$ and 21 , respectively (Figure 2).

The capacity for liver to oxidize $\left[1-{ }^{14} \mathrm{C}\right]$ palmitate to $\mathrm{CO}_{2}$ on $\mathrm{d}-21$ was correlated with the capacity of the liver to oxidize $\left[1-{ }^{14} \mathrm{C}\right]$ palmitate to $\mathrm{CO}_{2}$ on both $\mathrm{d}$ 1 and 21 relative to parturition (Table 4), indicating that cows with a high oxidative capacity prepartum 


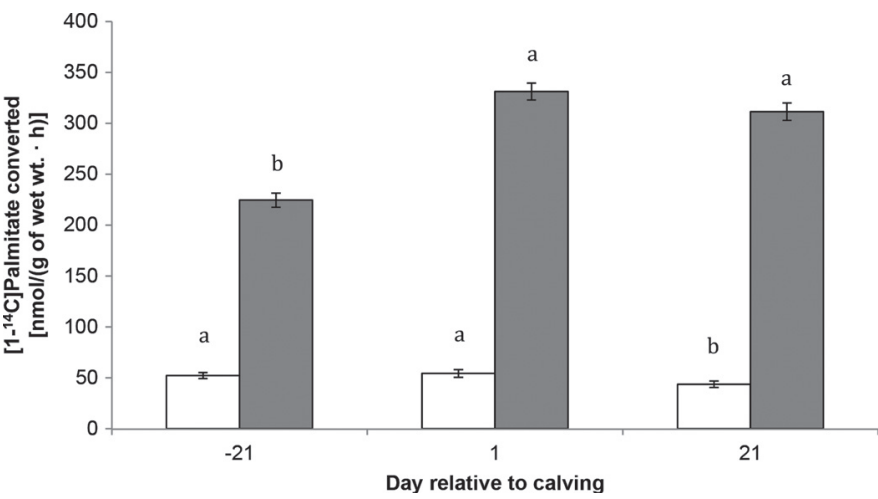

Figure 2. Rates of in vitro conversion of $\left[1-{ }^{14} \mathrm{C}\right]$ palmitate to $\mathrm{CO}_{2}$ (white bars) and stored esterified products (gray bars) in liver slices from transition dairy cows on $\mathrm{d}-21,1$, and 21 relative to calving. Rates of conversion of $\left[1-{ }^{14} \mathrm{C}\right]$ palmitate to $\mathrm{CO}_{2}$ were $52.1,54.2$, and $43.6 \mathrm{nmol}$ of converted/g of wet wt. $\times \mathrm{h}$ relative to calving and rates of conversion to esterified products were $224.5,331.1$, and $311.3 \mathrm{nmol}$ of converted/g of wet wt. $\times \mathrm{h}$ relative to calving. The effect of day relative to calving was significant for both $\mathrm{CO}_{2}(P<0.0001)$ and stored esterified products $(P<0.0001)$. Means with different letters are significantly different $(P=0.05)$; error bars represent $\mathrm{SE}$.

maintained a high oxidative capacity throughout the periparturient period. We detected a negative relationship between prepartum liver capacity to oxidize $\left[1-{ }^{14} \mathrm{C}\right]$ palmitate to $\mathrm{CO}_{2}$ and prepartum capacity for liver to convert $\left[1-{ }^{14} \mathrm{C}\right]$ palmitate to EP; however, there was no relationship on $\mathrm{d} 1$, and the relationships between palmitate oxidation and conversion to $\mathrm{EP}$ was positive on d 21 . On d 21, low-producing cows $(<36 \mathrm{~kg} /$ d average during the first 21 DIM) had a positive relationship between palmitate oxidation and conversion to $\mathrm{EP}(\mathrm{r}=$ $0.49 ; P=0.003)$; however, high-producing cows $(\geq 36$ $\mathrm{kg} / \mathrm{d}$ average during the first $21 \mathrm{DIM}$ ) had no relationship between palmitate oxidation and conversion to EP on $\mathrm{d} 21(\mathrm{r}=0.07 ; P=0.58)$. This alteration in the relationship postpartum between $\left[1-{ }^{14} \mathrm{C}\right]$ palmitate oxidation to $\mathrm{CO}_{2}$ and $\mathrm{EP}$ during the transition period and differences relative to early-lactation milk production could suggest that these processes are responding to the postpartum milk energy demands, negative energy balance, and the increases in NEFA mobilization and ketone body synthesis. During the postpartum period, there is a greater increase in partial oxidation to ketone bodies during early lactation (Zammit, 1990). Unfortunately in this data set, ketone body synthesis, using the in vitro conversion of $\left[1-{ }^{14} \mathrm{C}\right]$ palmitate to acid-soluble products as a proxy, was not measured. However, we could speculate that the lack of relationship between $\left[1-{ }^{14} \mathrm{C}\right]$ palmitate oxidation and conversion to EP on $\mathrm{d}$ 1 postpartum may be due to the increase in ketone synthesis during that period. Although the capacity of liver to convert $\left[1-{ }^{14} \mathrm{C}\right]$ palmitate to $\mathrm{CO}_{2}$ and $\mathrm{EP}$ at $-21 \mathrm{~d}$ was negatively correlated with prepartum NEFA AUC, Litherland et al. (2011) observed that NEFA on d 1 relative to parturition was strongly correlated with $\left[1-{ }^{14} \mathrm{C}\right]$ palmitate conversion to EP on $\mathrm{d} 1$. Although our data show a poor relationship between conversion to EP on $\mathrm{d} 1$ and postpartum NEFA AUC, the capacity of liver to convert $\left[1-{ }^{14} \mathrm{C}\right]$ palmitate to EP on d 21 was positively correlated with postpartum NEFA AUC and also postpartum BHBA AUC, indicating that as postpartum NEFA mobilization increases, the conversion of fatty acids to stored EP increases.

The capacity of liver slices to convert $\left[1-{ }^{14} \mathrm{C}\right]$ palmitate to $\mathrm{CO}_{2}$ at all time points was correlated negatively with the capacity to convert $\left[1-{ }^{14} \mathrm{C}\right]$ propionate to glucose at all time points. On d 21, the capacity of liver slices to convert $\left[1-{ }^{14} \mathrm{C}\right]$ palmitate to $\mathrm{CO}_{2}$ was correlated negatively with the capacity of liver to oxidize $\left[1-{ }^{14} \mathrm{C}\right]$ propionate to $\mathrm{CO}_{2}$ (Table 5), indicating that cows with increased $\left[1-{ }^{14} \mathrm{C}\right]$ palmitate oxidation have decreased $[1-$

Table 4. Pearson correlation ${ }^{1}$ among in vitro conversion of $\left[1-{ }^{14} \mathrm{C}\right]$ palmitate to $\mathrm{CO}_{2}$ and intracellularly stored esterified products (EP) across all other measured variables

\begin{tabular}{|c|c|c|c|c|c|c|}
\hline \multirow[b]{2}{*}{ Variable } & \multicolumn{3}{|c|}{ Palmitate to $\mathrm{CO}_{2}$} & \multicolumn{3}{|c|}{ Palmitate to EP } \\
\hline & $\mathrm{d}-21$ & d 1 & d 21 & $\mathrm{~d}-21$ & d 1 & d 21 \\
\hline Palmitate to $\mathrm{CO}_{2}$ d 1 & & 1.00 & $\begin{array}{l}0.735 \\
<0.0001\end{array}$ & $\begin{array}{l}-0.536 \\
<0.0001\end{array}$ & $\begin{array}{c}-0.091 \\
0.38\end{array}$ & $\begin{array}{l}0.071 \\
0.50\end{array}$ \\
\hline Palmitate to $\mathrm{CO}_{2}$ d 21 & & & 1.00 & $\begin{array}{l}-0.536 \\
<0.0001\end{array}$ & $\begin{array}{c}-0.241 \\
0.02\end{array}$ & $\begin{array}{l}0.247 \\
0.02\end{array}$ \\
\hline Palmitate to EP d 1 & & & & & 1.00 & $\begin{array}{l}0.289 \\
0.005\end{array}$ \\
\hline Palmitate to EP d 21 & & & & & & 1.00 \\
\hline
\end{tabular}

${ }^{1}$ Correlation coefficient (r) is the top number, with corresponding $P$-value beneath. 
${ }^{14} \mathrm{C}$ propionate oxidation. The oxidation of NEFA in the liver provides ATP that is needed for gluconeogenesis, and Andersen et al. (2002) reported increased capacity for palmitate conversion to $\mathrm{CO}_{2}$ in liver slices from early-lactation cows fed more-propiogenic diets compared with liver slices from cows fed less-propiogenic diets. Drackley et al. (2001) reported that liver slices from early postpartum cows have an increased propensity to convert propionate to glucose during early lactation. Together, these results may suggest that during early lactation, cows have increased ability to use propionate for glucose synthesis and that feeding more-propiogenic diets promotes more complete oxidation of acetyl CoA derived from mitochondrial $\beta$-oxidation of fatty acyl CoA.

\section{Hepatic Propionate Metabolism}

The capacity of liver to convert $\left[1-{ }^{14} \mathrm{C}\right]$ propionate to $\mathrm{CO}_{2}$ was 127 and $83 \%$ of prepartum values on $\mathrm{d} 1$ and 21 relative to parturition, and the capacity of liver to convert $\left[1-{ }^{14} \mathrm{C}\right]$ propionate to glucose was 126 and $85 \%$ of prepartum values on d 1 and 21 (Figure 3). In experiments using labeled isotopes, the $\left[1-{ }^{14} \mathrm{C}\right]$ propionate label randomizes in the tricarboxylic acid cycle such that every $1 \mathrm{~mol}$ of $\left[1-{ }^{14} \mathrm{C}\right]$ propionate that is directed toward oxaloacetate would yield $0.5 \mathrm{~mol}$ of radiolabeled $\mathrm{CO}_{2}$ and $0.5 \mathrm{~mol}$ of radiolabeled glucose (Knapp et al., 1992). Therefore, an increase in the ratio of labeled glucose to $\mathrm{CO}_{2}$ would suggest an increase in the efficiency of utilization of propionate for gluconeogenesis. However, because there were similar increases in both propionate oxidation and the capacity to convert propionate to glucose, there was no effect of time on the ratio of glucose to $\mathrm{CO}_{2}(P=0.91)$.

We detected a strong relationship between liver capacity for $\left[1-{ }^{14} \mathrm{C}\right]$ propionate oxidation to $\mathrm{CO}_{2}$ and conversion to glucose that increased with time (Table 6). There was a strong positive correlation between $\left[1-{ }^{14} \mathrm{C}\right]$ propionate conversion to glucose with the ratio of glucose to $\mathrm{CO}_{2}$ for all time points. This would be expected as the $\left[1-{ }^{14} \mathrm{C}\right]$ propionate conversion to glucose

Table 5. Pearson correlation ${ }^{1}$ among in vitro conversion of $\left[1-{ }^{14} \mathrm{C}\right]$ palmitate to $\mathrm{CO}_{2}$ and intracellularly stored esterified products (EP) across all other measured variables

\begin{tabular}{|c|c|c|c|c|c|c|}
\hline \multirow[b]{2}{*}{ Variable } & \multicolumn{3}{|c|}{ Palmitate to $\mathrm{CO}_{2}$} & \multicolumn{3}{|c|}{ Palmitate to EP } \\
\hline & $\mathrm{d}-21$ & d 1 & d 21 & $\mathrm{~d}-21$ & d 1 & d 21 \\
\hline \multirow{2}{*}{ Propionate to $\mathrm{CO}_{2}$ d 1} & $\begin{array}{c}0.82 \\
-0.168\end{array}$ & $\begin{array}{c}0.61 \\
-0.078\end{array}$ & $\begin{array}{c}0.69 \\
-0.085\end{array}$ & $\begin{array}{l}0.33 \\
0.080\end{array}$ & $\begin{array}{l}0.27 \\
0.087\end{array}$ & $\begin{array}{c}0.12 \\
-0.056\end{array}$ \\
\hline & 0.12 & 0.47 & 0.44 & 0.46 & 0.43 & 0.60 \\
\hline Propionate to $\mathrm{CO}_{2}$ d 21 & -0.254 & -0.266 & -0.264 & 0.393 & -0.023 & -0.142 \\
\hline Propionate to glucose $\mathrm{d}-21$ & 0.007 & 0.001 & 0.0008 & $<0.0001$ & 0.71 & 0.39 \\
\hline \multirow[t]{2}{*}{ Propionate to glucose d 1} & -0.315 & -0.283 & -0.272 & 0.234 & 0.092 & -0.071 \\
\hline & 0.003 & 0.008 & 0.01 & 0.03 & 0.40 & 0.52 \\
\hline \multirow[t]{2}{*}{ Propionate to glucose d 21} & -0.440 & -0.388 & -0.395 & 0.511 & 0.031 & -0.144 \\
\hline & $<0.0001$ & 0.0003 & 0.0002 & $<0.0001$ & 0.78 & 0.19 \\
\hline \multirow[t]{2}{*}{ Ratio of glucose to $\mathrm{CO}_{2} \mathrm{~d}-21$} & -0.404 & -0.445 & -0.434 & 0.479 & 0.036 & -0.037 \\
\hline & 0.0002 & $<0.0001$ & $<0.0001$ & $<0.0001$ & 0.75 & 0.74 \\
\hline NEFA AUC ${ }^{2}$ prepartum & 0.003 & 0.003 & 0.0003 & 0.0009 & 0.96 & 0.91 \\
\hline \multirow[t]{2}{*}{ NEFA AUC postpartum } & 0.146 & 0.065 & 0.113 & -0.007 & 0.081 & 0.258 \\
\hline & 0.17 & 0.54 & 0.29 & 0.94 & 0.45 & 0.01 \\
\hline \multirow[t]{2}{*}{ BHBA AUC prepartum } & 0.066 & 0.056 & 0.059 & -0.032 & 0.005 & 0.062 \\
\hline & 0.54 & 0.60 & 0.58 & 0.76 & 0.96 & 0.56 \\
\hline \multirow[t]{2}{*}{ BHBA AUC postpartum } & 0.307 & 0.289 & 0.359 & -0.190 & 0.070 & 0.376 \\
\hline & 0.003 & 0.006 & 0.0005 & 0.07 & 0.52 & 0.0003 \\
\hline \multirow[t]{2}{*}{ Milk yield first $21 \mathrm{~d}$} & -0.130 & -0.143 & -0.236 & 0.151 & 0.125 & -0.007 \\
\hline & 0.21 & 0.17 & 0.02 & 0.15 & 0.23 & 0.95 \\
\hline \multirow[t]{2}{*}{ DMI d -7 to 21} & -0.076 & -0.097 & -0.053 & -0.079 & -0.212 & -0.147 \\
\hline & 0.47 & 0.36 & 0.62 & 0.45 & 0.04 & 0.16 \\
\hline
\end{tabular}

${ }^{1}$ Correlation coefficient (r) is the top number, with corresponding $P$-value beneath.

${ }^{2}$ Area under the curve. 


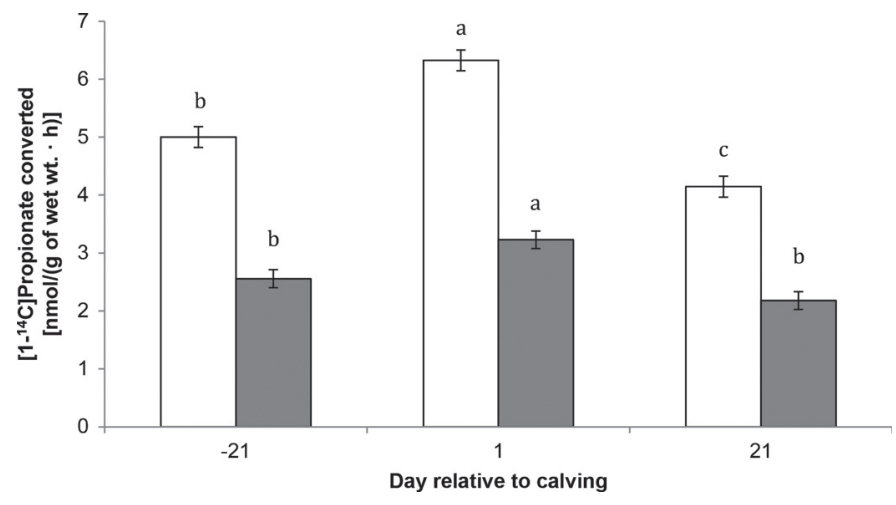

Figure 3. Rates of in vitro conversion of $\left[1-{ }^{14} \mathrm{C}\right]$ propionate to $\mathrm{CO}_{2}$ (white bars) and glucose (gray bars) in liver slices from transition dairy cows on $\mathrm{d}-21,1$, and 21 relative to calving. Rates of conversion of $\left[1-{ }^{14} \mathrm{C}\right]$ propionate to $\mathrm{CO}_{2}$ were $5.0,6.3$, and $4.1 \mu \mathrm{mol}$ converted/g wet wt. $\times \mathrm{h}$ relative to calving, and rates of conversion of $\left[1-{ }^{14} \mathrm{C}\right]$ propionate to glucose were $2.6,3.2$, and $2.2 \mu \mathrm{mol}$ converted/g wet wt. $\times \mathrm{h}$ relative to calving. The effect of day relative to calving was significant for both $\mathrm{CO}_{2}(P<0.0001)$ and glucose $(P<0.0001)$. Means with different letters are significantly different $(P=0.05)$; error bars represent SE.

is included as part of the calculated ratio; however, interestingly, we found no relationship between $\left[1-{ }^{14} \mathrm{C}\right]$ propionate oxidation to $\mathrm{CO}_{2}$ and the calculated ratio of glucose to $\mathrm{CO}_{2}$. The capacity for gluconeogenesis from $\left[1-{ }^{14} \mathrm{C}\right]$ propionate on d 21 was correlated negatively with both postpartum NEFA and BHBA AUC (Table 7), indicating that as hepatic propionate utilization increases, ketogenesis decreases. This is likely because succinyl CoA that is produced when propionate enters the citric acid cycle negatively inhibits 3-hydroxy-
3-methylglutaryl-CoA synthase, the rate-limiting step in ketone body synthesis (Zammit, 1990; Drackley et al., 2001). There was a positive relationship between cumulative milk yield during the first 21 DIM and [1$\left.{ }^{14} \mathrm{C}\right]$ propionate oxidation on $\mathrm{d} 21$ and $\left[1-{ }^{14} \mathrm{C}\right]$ propionate conversion to glucose. A positive relationship between cumulative milk yield during the first 21 DIM and the ratio of glucose to $\mathrm{CO}_{2}$ on $\mathrm{d} 1$ relative to parturition suggests that cows with an increased propensity to convert propionate to glucose very early postpartum have increased hepatic propionate metabolism in early lactation, leading to increased gluconeogenesis and early-lactation milk yield.

\section{CONCLUSIONS}

We detected decreases in hepatic glycogen content and increases in hepatic triglyceride content as cows transitioned to lactation. Similarly, the capacity of the liver to convert $\left[1-{ }^{14} \mathrm{C}\right]$ palmitate to EP increased during the postpartum period. The capacity of liver to convert $\left[1-{ }^{14} \mathrm{C}\right]$ propionate to $\mathrm{CO}_{2}$ and glucose also increased during the postpartum period. Hepatic gluconeogenesis from propionate was negatively correlated with both postpartum NEFA and BHBA AUC, suggesting that cows with greater NEFA mobilization and greater circulating BHBA have reduced gluconeogenic capacity from propionate. Similarly, correlation relationships suggest that excess liver triglyceride content is related to decreased capacity of the liver to convert propionate into glucose. Although there appear to be differences

Table 6. Pearson correlation ${ }^{1}$ among in vitro conversion of $\left[1-{ }^{14} \mathrm{C}\right]$ propionate to $\mathrm{CO}_{2}$ and glucose and the ratio of conversion to glucose and $\mathrm{CO}_{2}$ and all other measured variables

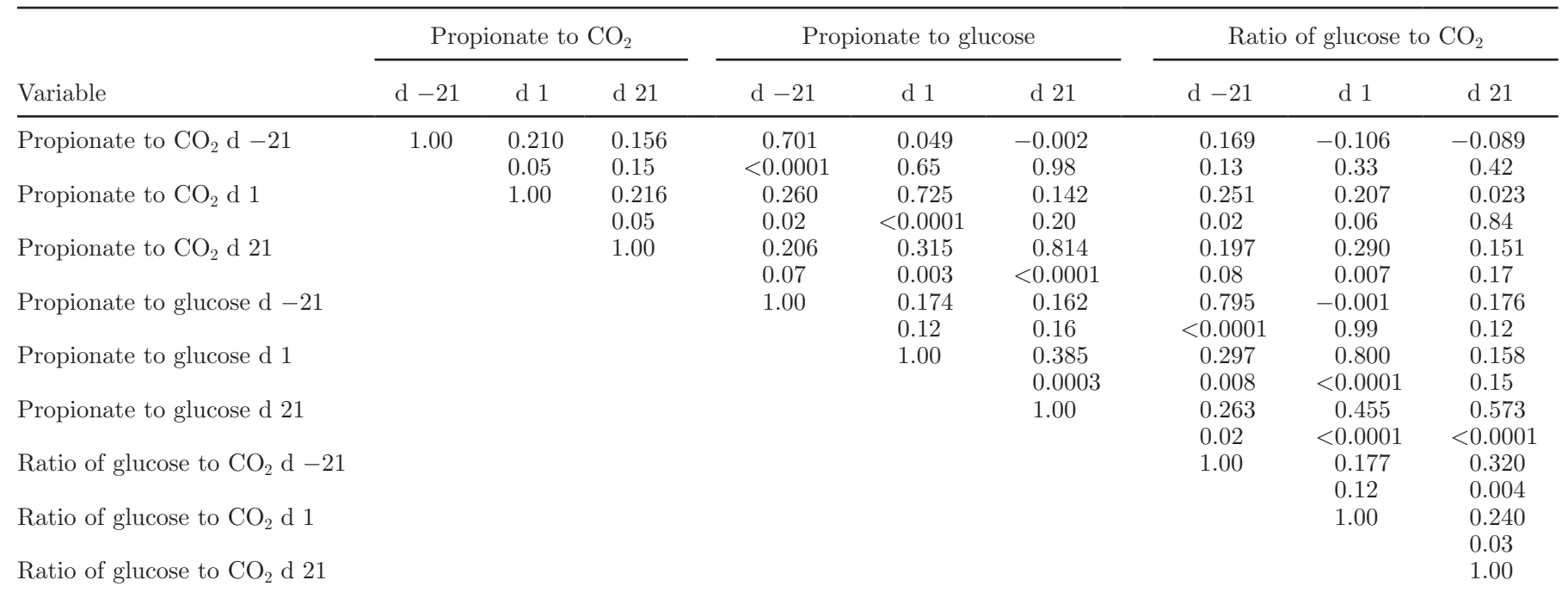

${ }^{1}$ Correlation coefficient (r) is the top number, with corresponding $P$-value beneath. 
Table 7. Pearson correlation ${ }^{1}$ among in vitro conversion of $\left[1-{ }^{14} \mathrm{C}\right]$ propionate to $\mathrm{CO}_{2}$ and glucose and the ratio of conversion to glucose and $\mathrm{CO}{ }_{2}$ and all other measured variables

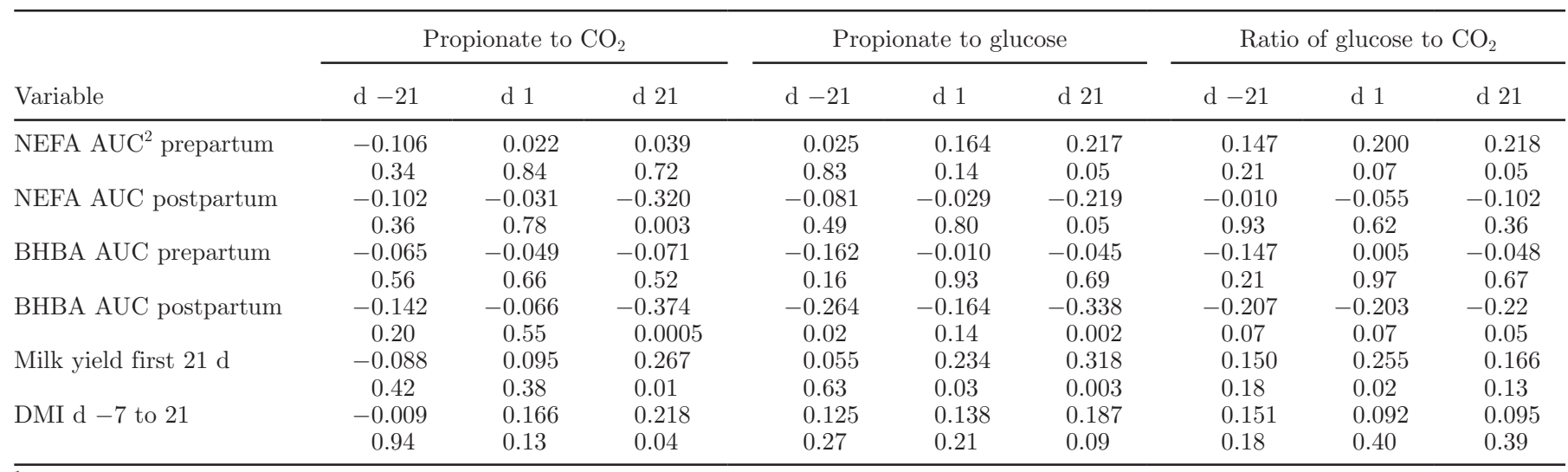

${ }^{1}$ Correlation coefficient (r) is the top number, with corresponding $P$-value beneath.

${ }^{2}$ Area under the curve.

in fatty acid metabolism based on production level, overall, alterations in fatty acid metabolism that lead to increased triglyceride accumulation during the transition period appear to impair postpartum hepatic gluconeogenesis.

\section{ACKNOWLEDGMENTS}

The authors sincerely appreciate and gratefully acknowledge the assistance of G. Birdsall and the staff at the Cornell University Dairy Teaching and Research Center (Ithaca, NY) for their care of the cows on the studies used in this analysis, as well as the assistance of R. (Slepetis) Ehrhardt (Cornell University) for her assistance with the in vitro incubations on all the studies used in this analysis.

\section{REFERENCES}

Andersen, J. B., T. Larsen, M. O. Nielsen, and K. L. Ingvartsen. 2002. Effect of energy density in the diet and milking frequency on hepatic long chain fatty acid oxidation in early lactating dairy cows. J. Vet. Med. A Physiol. Pathol. Clin. Med. 49:177-183.

Bauman, D. E., and W. B. Currie. 1980. Partitioning of nutrients during pregnancy and lactation: A review of mechanisms involving homeostasis and homeorhesis. J. Dairy Sci. 63:1514-1529.

Bell, A. W. 1995. Regulation of organic nutrient metabolism during transition from late pregnancy to early lactation. J. Anim. Sci. 73:2804-2819.

Bell, A. W., and D. E. Bauman. 1997. Adaptations of glucose metabolism during pregnancy and lactation. J. Mammary Gland Biol. Neoplasia 2:265-278.

Cardoso, F. C., W. Sears, S. J. LeBlanc, and J. K. Drackley. 2011. Technical note: Comparison of 3 methods for analyzing areas under the curve for glucose and nonesterified fatty acids concentrations following epinephrine challenge in dairy cows. J. Dairy Sci. 94:6111-6115.

Drackley, J. K. 1999. Biology of dairy cows during the transition period: The final frontier? J. Dairy Sci. 82:2259-2273.
Drackley, J. K., T. R. Overton, and G. N. Douglas. 2001. Adaptations of glucose and long-chain fatty acid metabolism in liver of dairy cows during the periparturient period. J. Dairy Sci. 84:E100E112.

Greenfield, R. B., M. J. Cecava, and S. S. Donkin. 2000. Changes in mRNA expression for gluconeogenic enzymes in liver of dairy cattle during the transition to lactation. J. Dairy Sci. 83:1228-1236.

Grum, D. E., J. K. Drackley, R. S. Younker, D. W. LaCount, and J. J. Veenhuizen. 1996. Nutrition during the dry period and hepatic lipid metabolism of periparturient dairy cows. J. Dairy Sci. 79:1850-1864.

Hammon, H. M., G. Stürmer, F. Schneider, A. Tuchscherer, H. Blum, T. Engelhard, A. Genzel, R. Staufenbiel, and W. Kanitz. 2009. Performance and metabolic and endocrine changes with emphasis on glucose metabolism in high-yielding dairy cows with high and low fat content in liver after calving. J. Dairy Sci. 92:1554-1566.

Knapp, J. R., H. C. Freetly, B. L. Reis, C. C. Calvert, and R. L. Baldwin. 1992. Effects of somatotropin and substrates on patterns of liver metabolism in lactating dairy cattle. J. Dairy Sci. 75:1025-1035.

Litherland, N. B., H. M. Dann, and J. K. Drackley. 2011. Prepartum nutrient intake alters palmitate metabolism by liver slices from peripartal dairy cows. J. Dairy Sci. 94:1928-1940.

Liu, L., X. Li, Y. Li, Y. Guan, Y. Song, L. Yin, H. Chen, L. Lei, J. Liu, X. Li, Z. Wang, X. Yang, and G. Liu. 2014. Effects of nonesterified fatty acids on the synthesis and assembly of very low density lipoprotein in bovine hepatocytes in vitro. J. Dairy Sci. 97:1328-1335.

Overton, T. R., and J. K. Drackley. 1999. Substrate utilization for hepatic gluconeogenesis is altered by increased glucose demand in ruminants. J. Anim. Sci. 77:1940-1951.

Piepenbrink, M. S. 2003. Nutritional modulators of hepatic energy metabolism during the periparturient period of dairy cattle. $\mathrm{PhD}$ Dissertation. Cornell University, Ithaca, NY.

Piepenbrink, M. S., A. L. Marr, M. R. Waldron, W. R. Butler, T. R. Overton, M. Vázquez-Añón, and M. D. Holt. 2004. Feeding 2-hydroxy-4-(methylthio)-butanoic acid to periparturient dairy cows improves milk production but not hepatic metabolism. J. Dairy Sci. 87:1071-1084.

Piepenbrink, M. S., and T. R. Overton. 2003. Liver metabolism and production of cows fed increasing amounts of rumen-protected choline during the periparturient period. J. Dairy Sci. 86:1722-1733.

Reynolds, C. K., P. C. Aikman, B. Lupoli, D. J. Humphries, and D. E. Beever. 2003. Splanchnic metabolism of dairy cows during the transition from late gestation through early lactation. J. Dairy Sci. 86:1201-1217. 
Reynolds, C. K., B. Dürst, B. Lupoli, D. J. Humphries, and D. E. Beever. 2004. Visceral tissue mass and rumen volume in dairy cows during the transition from late gestation to early lactation. J. Dairy Sci. 87:961-971.

Strang, B. D., S. J. Bertics, R. R. Grummer, and L. E. Armentano. 1998. Effect of long-chain fatty acids on triglyceride accumulation, gluconeogenesis, and ureagenesis in bovine hepatocytes. J. Dairy Sci. $81: 728-739$.

Vazquez-Añon, M., S. J. Bertics, M. Luck, R. R. Grummer, and J. Pinheiro. 1994. Peripartum liver triglyceride and plasma metabolites in dairy cows. J. Dairy Sci. 77:1521-1528.

Veenhuizen, J. J., J. K. Drackley, M. J. Richard, T. P. Sanderson, L. D. Miller, and J. W. Young. 1991. Metabolic changes in blood and liver during development and early treatment of experimental fatty liver and ketosis in cows. J. Dairy Sci. 74:4238-4253.
Weber, C., C. Hametner, A. Tuchscherer, B. Losand, E. Kanitz, W. Otten, H. Sauerwein, R. M. Bruckmaier, F. Becker, W. Kanitz, and H. M. Hammon. 2013a. Hepatic gene expression involved in glucose and lipid metabolism in transition cows: Effects of fat mobilization during early lactation in relation to milk performance and metabolic changes. J. Dairy Sci. 96:5670-5681.

Weber, C., C. Hametner, A. Tuchscherer, B. Losand, E. Kanitz, W. Otten, S. P. Singh, R. M. Bruckmaier, F. Becker, W. Kanitz, and H. M. Hammon. 2013b. Variation in fat mobilization during early lactation differently affects feed intake, body condition, and lipid and glucose metabolism in high-yielding dairy cows. J. Dairy Sci. 96:165-180.

Zammit, V. A. 1990. Ketogenesis in the liver of ruminants-Adaptations to a challenge. J. Agric. Sci. 115:155-162. 